Bull. Chem. Soc. Ethiop. 2014, 28(3), 441-450.

Printed in Ethiopia

DOI: http://dx.doi.org/10.4314/bcse.v28i3.13

ISSN 1011-3924

(c) 2014 Chemical Society of Ethiopia

\title{
APPLICATION OF VARIOUS TYPES OF ALUMINA AND NANO- $\gamma$-ALUMINA SULFURIC ACID IN THE SYNTHESIS OF $\alpha$-AMINONITRILES DERIVATIVES: COMPARATIVE STUDY
}

\author{
Abbas Teimouri ${ }^{1, *}$, Leila Ghorbanian ${ }^{2,3}$ and Athar Moatari ${ }^{1}$ \\ ${ }^{1}$ Chemistry Department, Payame Noor University, 19395-3697, Tehran, Iran \\ ${ }^{2}$ Torabinejad Dental Research Center and Department of Oral and Maxillofacial Pathology, \\ School of Dentistry, Isfahan University of Medical Sciences, Isfahan, Iran \\ ${ }^{3}$ Materials Engineering Department, Isfahan University of Technology, Isfahan, Iran
}

(Received August 29, 2013; revised May 14, 2014)

\begin{abstract}
An efficient and green protocol for the synthesis of $\alpha$-aminonitrile derivatives by one-pot reaction of different aldehydes with amines and trimethylsilyl cyanide has been developed using natural alumina, alumina sulfuric acid (ASA), nano- $\gamma$-alumina, nano- $\gamma$-alumina sulfuric acid (nano- $\gamma$-ASA) under microwave irradiation and solvent-free conditions. The advantages of methods are short reaction times, high yields, milder conditions and easy work up. The catalysts can be recovered for the subsequent reactions and reused without any appreciable loss of efficiency.
\end{abstract}

KEY WORDS: Nano- $\gamma$-alumina, Nano- $\gamma$-alumina sulfuric acid, Green synthesis, Microwave irradiation, $\alpha-$ aminonitriles derivatives

\section{INTRODUCTION}

$\alpha$-Aminonitriles are significantly important intermediates for the synthesis of a wide variety of amino acids, amides, diamines, and nitrogen-containing heterocycles [1]. Among the methods reported for the synthesis of $\alpha$-aminonitriles, nucleophilic addition of cyanide ion to imines (Strecker reaction), is of great importance to modern organic chemistry as it offers one of the most direct and viable methods for the synthesis of $\alpha$-aminonitriles [2].

Thus, several modifications of the Strecker reaction have been developed using a variety of cyanide reagents such as alkaline cyanides [3], $\mathrm{Et}_{2} \mathrm{AlCN}$ [4], $(\mathrm{EtO})_{2}-\mathrm{POCN}$ [5], $\mathrm{Zn}(\mathrm{CN})_{2}$ [6], $\mathrm{HCN}$ [7], $\mathrm{Bu}_{3} \mathrm{SnCN}$ [8], TMSCN [9], $\mathrm{K}_{4}\left[\mathrm{Fe}(\mathrm{CN})_{6}\right.$ ] [10], along with catalysts variant such as $\mathrm{InCl}_{3}$ [11], $\mathrm{BiCl}_{3}$ [12], $\mathrm{RhI}_{3}$ [13], $\mathrm{NiCl}_{2}$ [14], $\mathrm{RuCl}_{3}$ [15], montmorillonite $\mathrm{KSF}$ clay [16], silica sulfuric acid [17], silica-supported heteropoly acids [18], silica-bonded sulfamic acid [19], silica-based ionic liquids [20], $\mathrm{I}_{2}$ [21], xanthan sulfuric acid [22], Zr-MCM-41 nanoreactors [23], $\mathrm{Zr}-\mathrm{Cu}(\mathrm{OTf})_{2}$ [24], $\mathrm{K}_{2} \mathrm{PdCl}_{4}$ [25], Al-MCM-41 [26] and Ga-TUD-1 [27] under various reaction conditions homogeneously catalyze the Strecker-type reaction.

However, many of these methods require the use of expensive reagents, harsh conditions, extended reaction times, and also require tedious work-up that generates a large amount of toxic waste. In order to overcome these problems, recently one-pot procedures have been developed for this transformation [28].

Performance of chemical reactions under solvent-free condition is one of the best methods for the protection of environment from toxic and hazardous organic solvents, thus the solventfree condition is one of the ways to green chemistry [29].

In the recent years, the use of nano- $\gamma$-alumina and heterogeneous solid acid catalysts such as alumina sulfuric acid [30] and nano- $\gamma$-alumina sulfuric [31] have been received considerable interest to chemists due to their eco-friendly, easy preparation in nano-size, reusability and recovery, low cost, and high acid strength. These catalysts are actually sulfuric acid linked to alumina surface via covalent bond without the risks and disadvantages of sulfuric acid; such as

*Corresponding author. E-mail: a_teimouri@pnu.ac.ir 
nonreusability, waste production and scale-up problems. A question may rise here is what type of alumina is more effective in synthesis of $\alpha$-aminonitriles compounds.

In continuation of our investigations on the use of novel synthetic methodologies in a heterogeneous system through multi-component procedures [32, 33], here we present our recent studies on the synthesis of $\alpha$-aminonitriles derivatives by one-pot reaction of different aldehydes with amines and trimethylsilyl cyanides in the presence of natural alumina, alumina sulfuric acid, nano- $\gamma$-alumina, nano- $\gamma$-alumina sulfuric under microwave irradiation and solvent-free conditions.

\section{RESULTS AND DISCUSSION}

In an effort to develop an optimal catalytic system, various reaction parameters like effect of catalyst loading, and time for the preparation of $\alpha$-aminonitriles derivatives were studied. The results listed in Table 1 showed that the conversions were sensitive to the catalyst type. The results showed that nano- $\gamma$-alumina sulfuric acid promoted the reaction more effective than alumina sulfuric acid, nano- $\gamma$-alumina as far as the amount of catalyst and reaction times are concerned (Table 1 , entry 3 ).

One reason for increase the catalytic activity may be related to the number of available active sites. In order to evaluate the effect of the catalyst particle size on the catalytic activity, the results were compared with those obtained using alumina sulfuric acid (ASA). No good activity was observed in the presence of alumina sulfuric acid or natural alumina (Table 1, entries 7 and 15). In comparison with conventional methods, microwave irradiation reactions are cleaner and microwave irradiation decreased remarkably the reaction times. No side products were detected in these reactions. Microwave irradiation affords the respective products in only 5-10 min (see Table 1). 10\% of the expected product was obtained in the absence of catalyst. To further improve the yield and to optimize the reaction conditions, the same reaction was carried out in the presence of $(10 \mathrm{mg})$ of catalyst under similar conditions. Reaction with $10 \mathrm{mg}$ of the catalyst required a longer reaction time and the yield of product was dramatically increased up to $85 \%$ after irradiating the mixture for only $10 \mathrm{~min}$.

Table 1. Effect of catalyst type and amount of catalyst on the synthesis of $\alpha$-aminonitrile derivatives ${ }^{a}$.

\begin{tabular}{|l|l|c|c|c|}
\hline Entry & Catalyst & Catalyst loading $(\mathrm{mg})$ & Time (min) & Yield (\%) $^{\text {b }}$ \\
\hline 1 & & - & 120 & 10 \\
\hline 2 & Nano-ASA & 10 & 10 & 85 \\
\hline 3 & & 15 & 5 & 96 \\
\hline 4 & & 20 & 5 & 84 \\
\hline 5 & & 25 & 5 & 76 \\
\hline 6 & Alumina-sulfuric acid & 10 & 10 & 75 \\
\hline 7 & & 15 & 5 & 84 \\
\hline 8 & & 20 & 5 & 76 \\
\hline 9 & & 25 & 5 & 72 \\
\hline 10 & Nano- $\gamma$-alumina & 10 & 10 & 68 \\
\hline 11 & & 15 & 5 & 73 \\
\hline 12 & & 20 & 5 & 66 \\
\hline 13 & & 25 & 5 & 65 \\
\hline 14 & Natural alumina & 10 & 10 & 60 \\
\hline 15 & & 15 & 5 & 65 \\
\hline 16 & & 20 & 5 & 58 \\
\hline 17 & & 25 & 5 & 54 \\
\hline
\end{tabular}

${ }^{\mathrm{a} B e z a l d e h y d e}(1 \mathrm{mmol})$, aniline $(1 \mathrm{mmol})$ and trimethylsilyl cyanide $(1.5 \mathrm{mmol}) .{ }^{\mathrm{b}}$ Yields after isolation of products. 
To minimize the formation of by-products and to achieve good yield of the desired product, the reaction is optimized by varying the amount of catalyst (15, 20 and $25 \mathrm{mg}$ ). An increase in the amount of nano-ASA from 10 to $15 \mathrm{mg}$ increased the yield of the desired product to a great extent $(85-96 \%)$. The percentage yield of the product with 10, 15, 20 and $25 \mathrm{mg}$ of alumina sulfuric acid as the catalyst are $85 \%, 96 \%, 84 \%$ and $76 \%$, respectively (Table 1, entries 6-9). For the nano- $\gamma$-alumina and natural alumina as the catalyst, when the catalyst content was increased to $25 \mathrm{mg}$, the product yield decreased to $65 \%$ (Table 1, entry 13) and 54\% (Table 1, entry 17), respectively. Therefore, it was found that the use of $15 \mathrm{mg}$ of the catalyst was sufficient to promote the reaction, and higher amounts of the catalyst did not increase the yields significantly. The temperature and the MW power were also optimized and the best results were obtained using $15 \mathrm{mg}$ of nano-ASA at $90{ }^{\circ} \mathrm{C}$ and microwave power $(600 \mathrm{~W})$. No increase in yield was observed at higher temperatures, while lowering the temperature below $90{ }^{\circ} \mathrm{C}$ reduced the reaction rate.

On reaching the optimized conditions a wide range of $\alpha$-aminonitriles were synthesized by using aromatic aldehydes with electron-donating or electron-withdrawing groups. The results are shown in Table 2. Most of the aldehydes reacted efficiently with aniline and TMSCN to furnish the corresponding products 1a-g in excellent yields (65-96\%).

Table 2. Acid-catalyzed synthesis of $\alpha$-aminonitriles derivatives ${ }^{\mathrm{a}}$ under microwave irradiation and solventfree conditions.

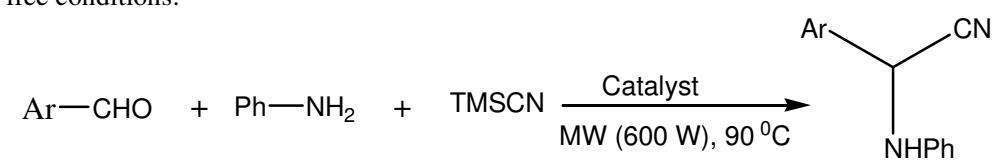

\begin{tabular}{|l|c|c|c|c|c|l|}
\hline \multirow{2}{*}{$\begin{array}{l}\text { Entry/ } \\
\text { Product }\end{array}$} & $\mathrm{Ar}$ & \multicolumn{4}{|c|}{ Time (min)/Yield (\%) } & \multirow{2}{*}{$\mathrm{MP}^{\mathrm{b}} \mathrm{C}$ (lit.) [Ref.] } \\
\cline { 1 - 6 } & & $\begin{array}{l}\text { Natural } \\
\text { alumina }\end{array}$ & $\begin{array}{l}\text { nano- } \gamma- \\
\text { alumina }\end{array}$ & $\begin{array}{l}\text { Alumi } \\
\text { na-SA }\end{array}$ & $\begin{array}{l}\text { nano- } \gamma- \\
\text { ASA }\end{array}$ & \\
\hline $1(\mathbf{1 a})$ & $\mathrm{Ph}$ & $12 / 65$ & $12 / 73$ & $12 / 84$ & $12 / 96$ & $72-74(75-76)[13]$ \\
\hline $2(\mathbf{1 b})$ & $4-\mathrm{NO}_{2} \mathrm{C}_{6} \mathrm{H}_{5}$ & $12 / 62$ & $12 / 65$ & $12 / 85$ & $12 / 93$ & $90-92$ \\
\hline $3(\mathbf{1 c})$ & $4-\mathrm{OHC}_{6} \mathrm{H}_{5}$ & $12 / 65$ & $12 / 69$ & $12 / 85$ & $12 / 90$ & $120-122(120-122)[25]$ \\
\hline $4(\mathbf{1 d})$ & $4-\mathrm{CH}_{3} \mathrm{C}_{6} \mathrm{H}_{5}$ & $12 / 64$ & $12 / 70$ & $12 / 86$ & $12 / 91$ & $70-72(74-76)[27]$ \\
\hline $5(\mathbf{1 e})$ & $4-\mathrm{OCH}_{3} \mathrm{C}_{6} \mathrm{H}_{5}$ & $12 / 64$ & $12 / 72$ & $12 / 89$ & $12 / 93$ & $94-96(92-94)[27]$ \\
\hline $6(\mathbf{1 f})$ & $4-\mathrm{ClC}_{6} \mathrm{H}_{5}$ & $12 / 62$ & $12 / 65$ & $12 / 86$ & $12 / 92$ & $108-110(108-110)[13]$ \\
\hline $7(\mathbf{1 g})$ & $4-\mathrm{BrC}_{6} \mathrm{H}_{5}$ & $12 / 60$ & $12 / 69$ & $12 / 84$ & $12 / 92$ & $100-102(101-103)[19]$ \\
\hline
\end{tabular}

abezaldehyde $(1 \mathrm{mmol})$, aniline $(1 \mathrm{mmol})$ and trimethylsilyl cyanide $(1.5 \mathrm{mmol})$. ${ }^{b}$ Isolated yields of products characterized by IR, ${ }^{1} \mathrm{H}$ NMR, and mass spectroscopy.

Table 3. Comparison of the efficiency of nano-ASA with other reported catalysts in the synthesis of $\alpha$ aminonitriles derivatives ${ }^{\mathrm{a}}$.

\begin{tabular}{|c|l|c|c|c|}
\hline Entry & Condition & Time $(\min )$ & Yield $(\%)^{\mathrm{b}}$ & References \\
\hline 1 & $\mathrm{Nano}-\mathrm{ASA}$ & 12 & 96 & This work \\
\hline 2 & $\mathrm{~K}_{4}\left[\mathrm{Fe}(\mathrm{CN})_{6}\right], \mathrm{EtOH}$ & 8 & 88 & 10 \\
\hline 3 & $\mathrm{BiCl}_{3} / \mathrm{CH}_{3} \mathrm{CN}, \mathrm{rt}$ & 10 & 84 & 12 \\
\hline 4 & $\mathrm{NiCl}_{2} / \mathrm{CH}_{3} \mathrm{CN}, \mathrm{rt}$ & 12 & 92 & 14 \\
\hline 5 & ${\mathrm{~K} 10 / \mathrm{CH}_{2} \mathrm{Cl}}_{2}$ & 3.5 & 90 & 16 \\
\hline 6 & $\mathrm{Al}-\mathrm{MCM}-41 / \mathrm{CH}_{2} \mathrm{Cl}_{2}$ & 24 & 95 & 18 \\
\hline 7 & $\mathrm{I}_{2} / \mathrm{CH} \mathrm{H}_{3} \mathrm{CN}, \mathrm{rt}$ & 1 & 94 & 21 \\
\hline 8 & $\mathrm{Ga}-\mathrm{TUD}-1 /$ solvent-free, rt & 0.5 & 95 & 27 \\
\hline
\end{tabular}

aldhyde, amine and trimethylsilyl cyanide in the presence of catalyt. ${ }^{\mathrm{b}}$ Isolated yields. 
Table 3 compares the efficiency of present method with the efficiency of other methods in the synthesis of $\alpha$-aminonitriles derivatives. As evident from Tables 3 , nano- $\gamma$-alumina sulfuric acid shows better efficiency than other methods.

A proposed mechanism for the rule of various types of alumina catalysts in the reaction of aromatic aldehyde, amine and trimethylsilyl cyanide is presented in Figure 1.

We propose a mechanism for the formation of $\alpha$-aminonitriles derivatives 1a-g it has been hypothesized that the reaction proceeds. First, aromatic aldehyde activated by the acidic proton of alumina reacts with amines to form a key intermediate. Finally, nucleophilic addition of cyanide ion to the intermediate, which is formed from condensation of aldehydes and amines, yields $\alpha$-aminonitriles derivatives.

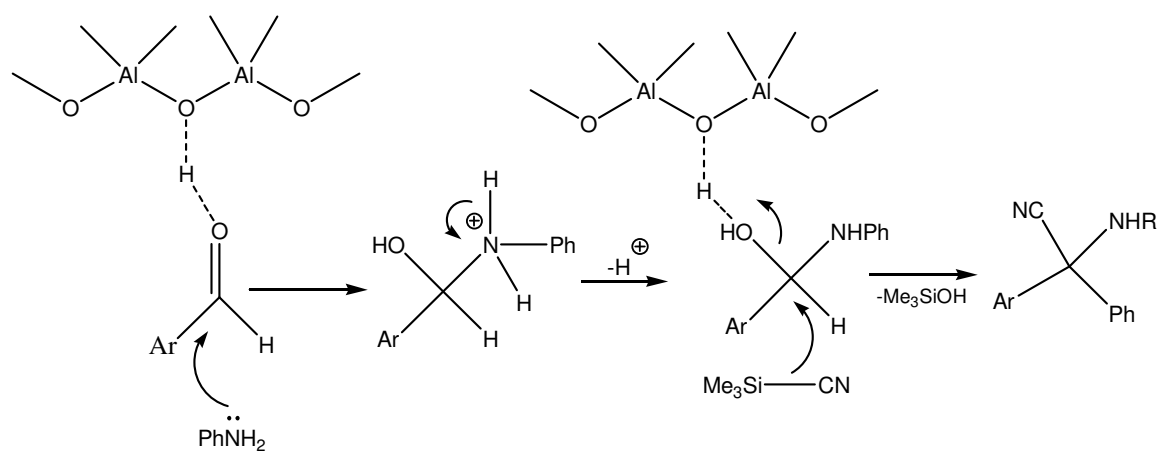

Figure 1. Proposed mechanism for one-pot synthesis of $\alpha$-aminonitriles derivatives.

\section{Characterization}

$\mathrm{X}$-ray diffraction pattern were recorded on diffractometer (Philips X'pert) using $\mathrm{Cu} \mathrm{K} \alpha$ radiation $(\lambda=1.5405 \AA)$, Crystallite size of the crystalline phase was determined from the peak of maximum intensity by using Scherrer formula with a shape factor $(\mathrm{K})$ of 0.9 , as below: Crystallite size $=K \cdot \lambda / \mathrm{W} \cdot \cos \theta$, where, $\mathrm{W}=\mathrm{W}_{\mathrm{b}}-\mathrm{W}_{\mathrm{s}}$ and $\mathrm{W}_{\mathrm{b}}$ is the broadened profile width of experimental sample and $\mathrm{W}_{\mathrm{s}}$ is the standard profile width of reference silicon sample. FT-IR spectra of the catalysts were recorded by FT-IR spectrophotometer in the range of 400-4000 $\mathrm{cm}^{-1}$ with a resolution of $4 \mathrm{~cm}^{-1}$ by mixing the sample with $\mathrm{KBr}$.

Figure 2 indicates the formation of crystallized alumina, as broad peaks indexed for $\gamma-\mathrm{Al}_{2} \mathrm{O}_{3}$ are seen in the XRD pattern, where small and broad peaks started appearing at $2 \theta=48^{\circ}$ and at $2 \theta=67^{\circ}$. The broadening of the XRD peaks revealed the nano-size nature of $\gamma-\mathrm{Al}_{2} \mathrm{O}_{3}$ particles in alumina samples.

The XRD patterns of nano- $\gamma$-alumina sulfuric acid obtained. Characteristic peaks appeared at $2 \theta=31.7,34.5,36.2$ and 56.5 (Figure 3). The XRD patterns of the synthesized nano- $\gamma$ alumina sulfuric acid show the crystallization of structures.

The FT-IR spectra of alumina samples calcined at $550{ }^{\circ} \mathrm{C}$ (Figure 4) showed an intense band centered around $3500 \mathrm{~cm}^{-1}$ and a broad band at $1640 \mathrm{~cm}^{-1}$, these are assigned to stretching and bending modes of adsorbed water. The Al-O-Al bending stretching vibrations observed at around $1125 \mathrm{~cm}^{-1}$ are due to symmetric and asymmetric bending modes, respectively. The $\mathrm{OH}$ torsional mode observed at $800 \mathrm{~cm}^{-1}$ overlaps with $\mathrm{Al}-\mathrm{O}$ stretching vibrations. The weak band at $2091 \mathrm{~cm}^{-1}$ is assigned to a combination band. Bands observed at $480-650 \mathrm{~cm}^{-1}$ are attributable to stretching and bending modes of $\mathrm{AlO}_{6}[36]$. 
The FT-IR spectra of nano- $\gamma$-alumina sulfuric acid showed peaks at $605,889,1010-1080$ and 1120-1230 $\mathrm{cm}^{-1}$ corresponded to asymmetric and symmetric stretching modes of $\mathrm{SO}_{2}$ groups, that is a good reason for functionalization of nano- $\gamma$-alumina by chlorosulfonic acid. The spectrum also shows a broad $\mathrm{OH}$ stretching absorption around $3000-3700 \mathrm{~cm}^{-1}$ (Figure 4).

The morphology of the catalysts was studied. SEM micrograph nano- $\gamma$-alumina sulfuric acid have been presented in Figure 5. The SEM picture showed that the particles were of irregular shape with a wide size distribution. A part of the spectra data has been published in our previous work [32].

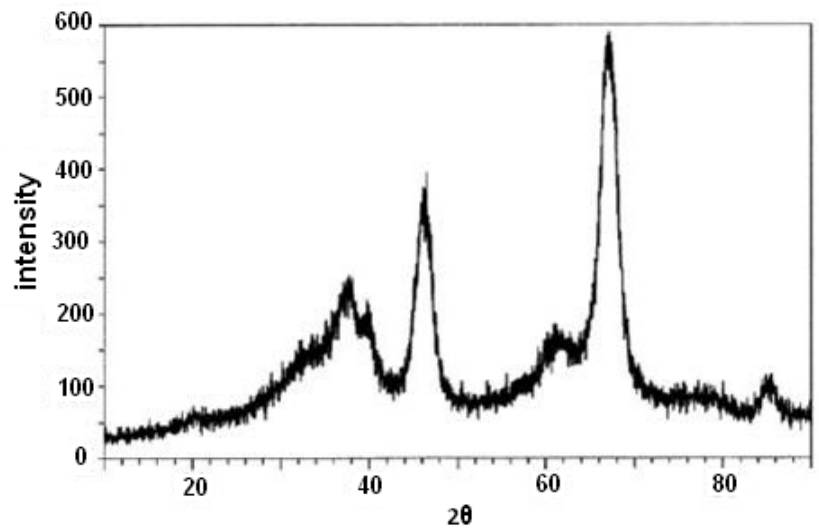

Figure 2. XRD pattern of nano- $\gamma$-alumina catalyst.

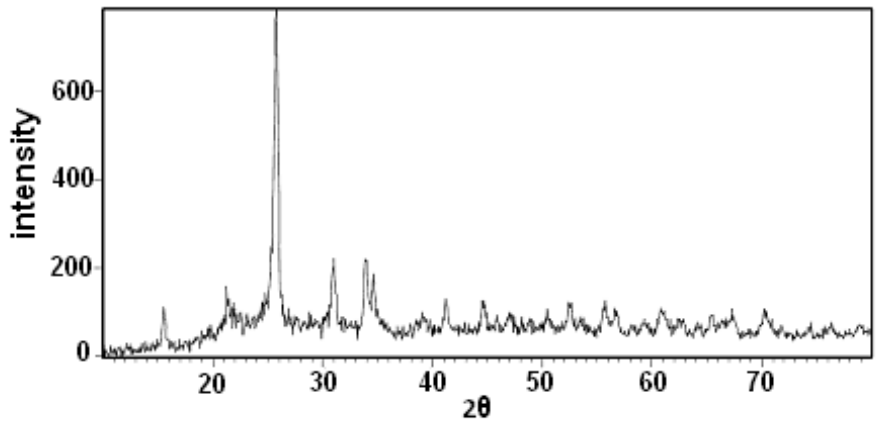

Figure 3. XRD pattern of nano- $\gamma$-alumina sulfuric acid catalyst. 


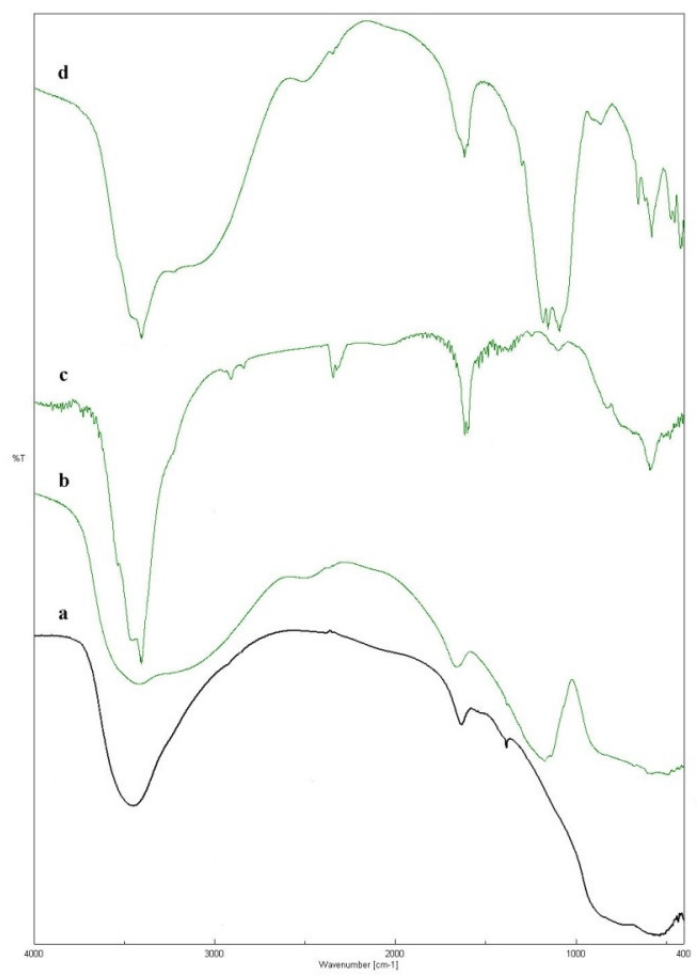

Figure 4. FT-IR spectra of a) alumina, b) alumina sulfuric acid, c) nano- $\gamma$-alumina and d) nano$\gamma$-alumina sulfuric acid catalysts.

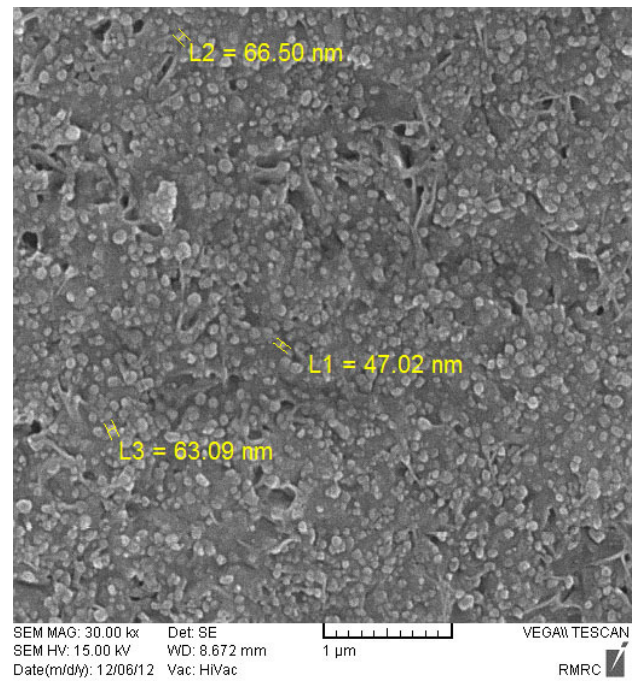

Figure 5. SEM micrograph of nano- $\gamma$-alumina sulfuric acid catalyst.

Bull. Chem. Soc. Ethiop. 2014, 28(3) 
Catalysts successfully recycled (after thorough washing and activation) with little variation of yield. The recovery and reusability of the catalyst was investigated in the product formation. After completion of the reaction, the catalyst was separated by filtration, washed 3 times with 5 $\mathrm{mL}$ acetone, then with doubly distilled water several times and dried at $110{ }^{\circ} \mathrm{C}$. Then the recovered catalyst was used in the next run (Figure 6).

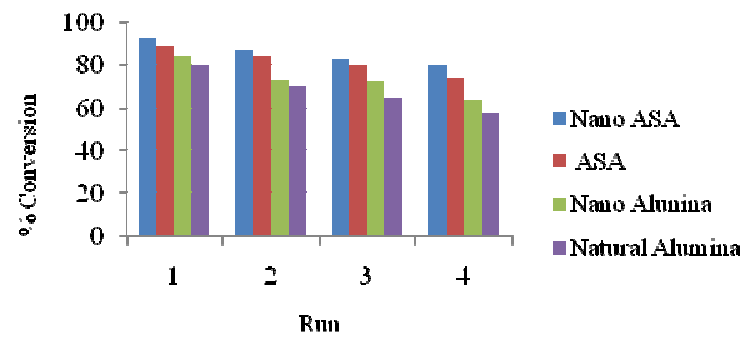

Figure 6. Change of the catalyst activity in the four consecutive runs.

\section{CONCLUSIONS}

In conclusion, we have demonstrated an efficient, versatile and convenient method for the synthesis of $\alpha$-aminonitriles derivatives in reaction of different aromatic aldehyde with acyl hydrazide under microwave irradiation without solvent. A comparison of the catalytic efficiency of natural alumina, alumina sulfuric acid, nano- $\gamma$-alumina, nano- $\gamma$-alumina sulfuric acid with the nano- $\gamma$-alumina sulfuric acid exhibiting greater activity has also been demonstrated. Compared to previously reported methods, Moreover, the mild reaction conditions, high yields, easy workup, clean reaction profiles and lower catalyst loading render this approach as an interesting alternative to the existing methods.

\section{EXPERIMENTAL}

All reagents were purchased from Merck and used without further purification. Products were characterized by spectroscopy data (IR, FTIR, ${ }^{1} \mathrm{H}$ NMR and ${ }^{13} \mathrm{C}$ NMR spectra), elemental analysis $(\mathrm{CHN})$ and melting points. The structural morphology of the samples was evaluated using scanning electron microscope (SEM). The samples were analyzed by X-ray diffraction (XRD) using Philips X'PERT MPD X-ray diffractometer (XRD). A JASCO FT/IR-680 PLUS spectrometer was used to record IR spectra using $\mathrm{KBr}$ pellets. NMR spectra were recorded on a Bruker 400 Ultrasheild NMR and DMSO- $\mathrm{d}_{6}$ was used as solvent. Melting points reported were determined by open capillary method using a Galen Kamp melting point apparatus and are uncorrected. Mass spectra were recorded on a Shimadzu Gas Chromatograph Mass Spectrometer GCMS-QP5050A/Q P5000 apparatus. The reactions were performed using a microwave oven with a power of $600 \mathrm{~W}$ specially designed for organic synthesis.

\section{Catalyst preparation}

\section{Preparation of alumina-sulfuric acid}

The alumina-sulfuric acid was prepared according to the procedure described earlier [34]. A 500 $\mathrm{mL}$ suction flask was used. It was equipped with a constant pressure dropping funnel containing freshly distilled chlorosulfonic acid $(2.75 \mathrm{~mL}, 41.2 \mathrm{mmol})$ was charged with neutral alumina (10 
g, $100 \mathrm{mmol}$ ) dried at $120^{\circ} \mathrm{C}$ for $2 \mathrm{~h}$ with stirring. Chlorosulfonic acid was added dropwise over a period of $30 \mathrm{~min}$ at room temperature. The liberated $\mathrm{HCl}$ was removed through a $\mathrm{CaCl}_{2}$ drying tube under reduced pressure to a water trap. Then it was kept in this condition for $1 \mathrm{~h}$ at room temperature, was washed with distilled water several times, ethanol (2 times) and dried at 130 ${ }^{\circ} \mathrm{C}$ for $4 \mathrm{~h}$

Synthesis of nano- $\gamma$-alumina catalyst

The nano- $\gamma$-alumina was prepared by sol-gel method according to a described procedure [35]. In a typical experiment, aluminum nitrate $(15.614 \mathrm{~g})$ was added to $400 \mathrm{~mL}$ of deionized water. Similarly solution of sodium carbonate was prepared by dissolving $(7.95 \mathrm{~g})$ in $400 \mathrm{~mL}$ of deionized water. $200 \mathrm{~mL}$ of deionized water was taken in a 21 capacity round-bottom flask and stirred well using magnetic stirrer. Then sodium carbonate and aluminum nitrate solutions were added to $200 \mathrm{~mL}$ of deionized water (from separate burettes) drop wise.

The temperature was maintained $70{ }^{\circ} \mathrm{C}$ during experiment. The $\mathrm{pH}$ after precipitation was found to be in the range of 7.5-8.5. The mixture was stirred for $4 \mathrm{~h}$. The digested precipitates were filtered and re-dispersed again in hot $2 \mathrm{~L}$ of deionized water, filtered and finally washed with ethanol first followed by acetone to avoid contamination of ' $\mathrm{Na}$ ' ions; and air dried at room temperature. The dried precipitates were calcined in a furnace at $550{ }^{\circ} \mathrm{C}$ for $5 \mathrm{~h}$ to produce nanosized $\gamma-\mathrm{Al}_{2} \mathrm{O}_{3}$ powders.

Synthesis of nano- $\gamma$-ASA

For synthesis of nano- $\gamma$-ASA, in a $500 \mathrm{~mL}$ round-bottom flask, chlorosulfonic acid $(1.35 \mathrm{~mL})$ was added dropwise to the high surface area nano- $\gamma$-alumina $(5 \mathrm{~g})$ over a period of $30 \mathrm{~min}$ at room temperature. The components were mixed with constant stirring about $30 \mathrm{~min}$ at ambient temperature to afford the nano-ASA as a uniform white solid. The liberated $\mathrm{HCl}$ was removed through a $\mathrm{CaCl}_{2}$ drying tube under reduced pressure to a water trap. The solid phase obtained was washed with distilled water several times, dried at $130{ }^{\circ} \mathrm{C}$ for $4 \mathrm{~h}$.

\section{General procedure for the synthesis of $\alpha$-aminonitriles derivatives}

To the reaction mixture of aldehyde $(1 \mathrm{mmol})$, amine $(1 \mathrm{mmol})$, trimethylsilyl cyanide $(1.5$ mmol) catalyst $(10 \mathrm{mg})$ was subjected to microwave irradiation $(600 \mathrm{~W})$ at $90{ }^{\circ} \mathrm{C}$ for $15 \mathrm{~min}$. The reaction was monitored by TLC. After completion of the reaction, as indicated by TLC, the reaction mixture was filtered and washed with EtOAc $(2 \times 20 \mathrm{~mL}$ and the catalyst was separated by filtration. The organic solvent was removed under reduced pressure. After purification by chromatography on silica gel (ethyl acetate/n-hexane 20:80) $\alpha$-aminonitriles were obtained.

2-(N-anilino)-2-phenyl acetonitrile (1a). M.p.: 72-74 ${ }^{\circ} \mathrm{C}$. FTIR $(\mathrm{KBr})\left(v_{\max }, \mathrm{cm}^{-1}\right): 3334,3023$, 2946, 2234, 1603, 1517, 1280, 954, $750 \mathrm{~cm}^{-1} .{ }^{1} \mathrm{H}$ NMR (400 MHz, DMSO-d $\left.\mathrm{d}_{6}\right): \delta_{\mathrm{H}}: 3.98$ (bs, $1 \mathrm{H}), 5.42(\mathrm{~s}, 1 \mathrm{H}), 6.74(\mathrm{~d}, \mathrm{~J}=7.6 \mathrm{~Hz}, 2 \mathrm{H}), 6.86(\mathrm{t}, \mathrm{J}=7.4 \mathrm{~Hz}, 1 \mathrm{H}), 7.24(\mathrm{t}, J=7.6 \mathrm{~Hz}, 2 \mathrm{H}), 7.40$ $(\mathrm{m}, 3 \mathrm{H}), 7.58(\mathrm{~m}, 2 \mathrm{H}) ;{ }^{13} \mathrm{C} \mathrm{NMR}\left(100 \mathrm{MHz}, \mathrm{DMSO}_{6}\right): \delta_{\mathrm{C}}: 49.88,114.19,118.14,119.95$, $127.29,129.33,129.61,129.56,133.99,144.56$. MS $(\mathrm{m} / \mathrm{z}): 208.10\left(\mathrm{M}^{+}\right)$. Anal. calcd for $\mathrm{C}_{14} \mathrm{H}_{12} \mathrm{~N}_{2}$ : C, 80.74; H, 5.81; N, 13.45. Found: C, 80.56; H, 5.63; N, 13.32 .

2-(4-Nitrophenyl)-2-(phenylamino) acetonitrile $(\mathbf{l b})$. M.p.: 90-92 ${ }^{\circ} \mathrm{C}$. FTIR $(\mathrm{KBr})\left(v_{\max }, \mathrm{cm}^{-1}\right)$ : 3312, 3019, 2246, 1666, 1590, 1466, 1103, $756 \mathrm{~cm}^{-1} .{ }^{1} \mathrm{H}$ NMR (400 MHz, DMSO-d 6 ): $\delta_{\mathrm{H}}: 4.13$ $(\mathrm{d}, \mathrm{J}=8.0 \mathrm{~Hz}, 1 \mathrm{H}), 5.20(\mathrm{~d}, \mathrm{~J}=8.0 \mathrm{~Hz}, 1 \mathrm{H}), 6.64(\mathrm{~d}, \mathrm{~J}=8.0 \mathrm{~Hz}, 2 \mathrm{H}), 6.75(\mathrm{t}, \mathrm{J}=7.8 \mathrm{~Hz}, 1 \mathrm{H})$, $7.05(\mathrm{t}, \mathrm{J}=7.8 \mathrm{~Hz}, 2 \mathrm{H}), 7.52(\mathrm{~d}, \mathrm{~J}=8.05 \mathrm{~Hz}, 2 \mathrm{H}), 7.95(\mathrm{~d}, \mathrm{~J}=8.05 \mathrm{~Hz}, 2 \mathrm{H}) ;{ }^{13} \mathrm{C}$ NMR $(100$ MHz, DMSO-d $\left.{ }_{6}\right): \delta_{\mathrm{C}}: 49.31,114.32,115.74,118.18,119.46,123.91,127.84,129.33,144.89$, 
156.63. MS (m/z): $253.09\left(\mathrm{M}^{+}\right)$. Anal. calcd for $\mathrm{C}_{14} \mathrm{H}_{11} \mathrm{~N}_{3} \mathrm{O}_{2}$ : C, 66.40; H, 4.38; N, 16.59 . Found: C, 66.29; H, 4.22; N, 16.43.

2-(N-Anilino)-2-(4-hydroxyphenyl) acetonitrile (1c). M.p.: $120-122{ }^{\circ} \mathrm{C}$. FTIR $(\mathrm{KBr})\left(v_{\max }, \mathrm{cm}^{-1}\right)$ : 3344, 3029, 2236, 1606, 1263, 1157, 834, $748 \mathrm{~cm}^{-1}$. ${ }^{1} \mathrm{H}$ NMR (400 MHz, DMSO-d $\left.{ }_{6}\right): \delta_{\mathrm{H}}: 4.53$ (br s, 1H), $5.16(\mathrm{~s}, 1 \mathrm{H}), 6.75-6.90(\mathrm{~m}, 5 \mathrm{H}), 7.23(\mathrm{t}, \mathrm{J}=7.4 \mathrm{~Hz}, 2 \mathrm{H}), 7.38(\mathrm{~d}, \mathrm{~J}=8.2 \mathrm{~Hz}, 2 \mathrm{H})$, 9.81 (br s, $1 \mathrm{H}) ;{ }^{13} \mathrm{C}$ NMR $\left(100 \mathrm{MHz}, \mathrm{DMSO}-\mathrm{d}_{6}\right): \delta_{\mathrm{C}}: 49.36,113.78,115.65,118.48,119.29$, 124.31, 128.46, 129.13, 145.39, 156.28. MS (m/z): $224.09\left(\mathrm{M}^{+}\right)$. Anal. calcd for $\mathrm{C}_{14} \mathrm{H}_{12} \mathrm{~N}_{2} \mathrm{O}: \mathrm{C}$, 74.98; H, 5.39; N, 12.49. Found: C, 74.71; H, 5.21; N, 12.33.

2-(N-Anilino)-2-(4-methylphenyl) acetonitrile (1d). M.p.: 70-72 ${ }^{\circ} \mathrm{C}$. FTIR (KBr) $\left(v_{\max }, \mathrm{cm}^{-1}\right)$ : $3311,3025,2236,1665,1559,1254,1121,761 \mathrm{~cm}^{-1}$. ${ }^{1} \mathrm{H}$ NMR $\left(400 \mathrm{MHz}, \mathrm{DMSO}-\mathrm{d}_{6}\right): \delta_{\mathrm{H}}: 2.36$ $(\mathrm{s}, 3 \mathrm{H}), 3.52(\mathrm{bs}, 1 \mathrm{H}), 5.31(\mathrm{~s}, 1 \mathrm{H}), 6.61(\mathrm{~d}, J=7.6 \mathrm{~Hz}, 2 \mathrm{H}), 6.75(\mathrm{t}, J=7.5 \mathrm{~Hz}, 1 \mathrm{H}), 7.14(\mathrm{t}, J=$ $8.0 \mathrm{~Hz}, 4 \mathrm{H}), 7.64(\mathrm{~d}, J=8.1 \mathrm{~Hz}, 2 \mathrm{H}) ;{ }^{13} \mathrm{C}$ NMR $\left(100 \mathrm{MHz}, \mathrm{DMSO}-\mathrm{d}_{6}\right): \delta_{\mathrm{C}}: 21.42,50.13$, $114.33,117.93,120.16,127.09,129.44,129.90,131.18,139.42,145.15$. MS (m/z): 222.12 $\left(\mathrm{M}^{+}\right)$. Anal. calcd for $\mathrm{C}_{15} \mathrm{H}_{14} \mathrm{~N}_{2}$ : C, 81.08; H, 6.35; N, 12.59. Found: $\mathrm{C}, 65.20 ; \mathrm{H}, 6.21 ; \mathrm{N}, 12.43$.

2-(N-anilino)-2-(4-methoxy-phenyl)-acetonitrile (1e). M.p.: 94-96 ${ }^{\circ} \mathrm{C}$. FTIR $(\mathrm{KBr})\left(v_{\max }, \mathrm{cm}^{-1}\right)$ : 3432, 2920, 2234, 1596, 1512, 1245, 1176, 822, 746, $680 \mathrm{~cm}^{-1} .{ }^{1} \mathrm{H}$ NMR (400 MHz, DMSO-d 6 ): $\delta_{\mathrm{H}}: 3.82(\mathrm{~s}, 3 \mathrm{H}), 3.94(\mathrm{~s}, 1 \mathrm{H}), 5.32(\mathrm{~s}, 1 \mathrm{H}), 6.74(\mathrm{~d}, J=8.7 \mathrm{~Hz}, 2 \mathrm{H}), 6.89(\mathrm{t}, J=7.4 \mathrm{~Hz}, 1 \mathrm{H})$, $6.96(\mathrm{~d}, J=8.8 \mathrm{~Hz}, 2 \mathrm{H}), 7.22(\mathrm{t}, J=7.2 \mathrm{~Hz}, 2 \mathrm{H}), 7.46(\mathrm{~d}, J=8.7 \mathrm{~Hz}, 2 \mathrm{H}) ;{ }^{13} \mathrm{C} \mathrm{NMR}(100 \mathrm{MHz}$, DMSO-d $\left.)_{6}\right): \delta_{\mathrm{C}}: 49.78,55.66,114.14,114.63,118.40,120.20,126.12,128.62,129.58,144.73$, 160.43. MS (m/z): $238.11\left(\mathrm{M}^{+}\right)$. Anal. calcd for $\mathrm{C}_{15} \mathrm{H}_{14} \mathrm{~N}_{2} \mathrm{O}: \mathrm{C}, 75.45 ; \mathrm{H}, 5.58 ; \mathrm{N}, 11.70$. Found: C, $75.34 ; \mathrm{H}, 5.38 ; \mathrm{N}, 11.56$.

2-(N-anilino)-2-(4-chlorophenyl) acetonitrile (If). M.p.: $108-110{ }^{\circ} \mathrm{C}$. FTIR $(\mathrm{KBr})\left(v_{\max }, \mathrm{cm}^{-1}\right)$ : 3316, 3026, 2950, 2239, 1606, 1458, 1263, 1240, 887, $758 \mathrm{~cm}^{-1}$. ${ }^{1} \mathrm{H}$ NMR (400 MHz, DMSO$\left.\mathrm{d}_{6}\right): \delta_{\mathrm{H}}: 4.04(\mathrm{bs}, 1 \mathrm{H}), 5.42(\mathrm{~s}, 1 \mathrm{H}), 6.74(\mathrm{~d}, 2 \mathrm{H}, J=7.6 \mathrm{~Hz}), 6.91(\mathrm{t}, 1 \mathrm{H}, J=7.4 \mathrm{~Hz}), 7.26(\mathrm{t}, 2 \mathrm{H}$, $J=8.9 \mathrm{~Hz}), 7.48(\mathrm{~d}, 2 \mathrm{H}, J=8 \mathrm{~Hz}), 7.54(\mathrm{~d}, 2 \mathrm{H}, J=8 \mathrm{~Hz}) ;{ }^{13} \mathrm{C}$ NMR $\left(100 \mathrm{MHz}\right.$, DMSO- $\left.\mathrm{d}_{6}\right): \delta_{\mathrm{C}}$ : $164.73,164.33,142.26,131.60,129.76,129.03,126.88,124.04,121.16,21.66 . \mathrm{MS}(\mathrm{m} / \mathrm{z})$ : $242.06\left(\mathrm{M}^{+}\right)$. Anal. calcd for $\mathrm{C}_{14} \mathrm{H}_{11} \mathrm{ClN}_{2}$ : C, 69.28; H, 4.57; N, 11.54. Found: $\mathrm{C}, 69.11 ; \mathrm{H}, 4.43$; $\mathrm{N}, 11.32$.

2-(4-Bromophenylamino)-2-phenylacetonitrile (1g). M.p.: 100-102 ${ }^{\circ} \mathrm{C}$. FTIR $(\mathrm{KBr})\left(v_{\max }, \mathrm{cm}^{-1}\right)$ : $3325,3038,2963,2235,1599,1228,928,762 \mathrm{~cm}^{-1} .{ }^{1} \mathrm{H}$ NMR (100 MHz, DMSO-d $\left.\mathrm{d}_{6}\right): \delta_{\mathrm{H}}: 3.98$ $(\mathrm{sb}, 1 \mathrm{H}), 5.32(\mathrm{~s}, 1 \mathrm{H}), 6.64(\mathrm{~d}, 2 \mathrm{H}, J=8.3 \mathrm{~Hz}), 6.64(\mathrm{t}, 1 \mathrm{H}), 7.19(\mathrm{t}, 2 \mathrm{H}), 7.30(\mathrm{~d}, 2 \mathrm{H}, J=8.3$ $\mathrm{Hz}), 7.52(\mathrm{~m}, 2 \mathrm{H}) .{ }^{13} \mathrm{C}$ NMR $\left(400 \mathrm{MHz}, \mathrm{DMSO}-\mathrm{d}_{6}\right): \delta_{\mathrm{C}}: 49.94,113.42,116.71,119.81,124.46$, 128.62, 129.66, 132.37, 133.44, 143.38. MS (m/z): $286.01\left(\mathrm{M}^{+}\right)$. Anal. calcd for $\mathrm{C}_{14} \mathrm{H}_{11} \mathrm{BrN}_{2}: \mathrm{C}$, 58.56; H, 3.86; N, 9.76. Found: C, 58.44; H, 3.56; N, 9.63.

\section{ACKNOWLEDGEMENTS}

Supports from the Payame Noor University in Isfahan Research Council and helps of Isfahan University of Technology are gratefully acknowledged. The authors are also thankful to Mr. M. Narimani, for providing useful chemicals.

\section{REFERENCES}

1. Duthaler, R.O. Tetrahedron 1994, 50, 1539.

2. Groger, H. Chem. Rev. 2003, 103, 2795. 
3. Kobayashi, S.; Ishitani, H. Chem. Rev. 1999, 99, 1069.

4. Nakamura, S.; Sato, N.; Sugimoto, M.; Toru, T. Tetrahedron: Asymmetry 2004, 15, 1513.

5. Harusawa, S.; Hamada, Y.; Shioiri, T. Tetrahedron Lett. 1979, 20, 4663.

6. Shah, S.; Singh, B. Tetrahedron Lett. 2012, 53, 151.

7. Enders, D.; Shilvock, J. P. Chem. Soc. Rev. 2000, 29, 359.

8. Xie, Z.F.; Li, G.L.; Zhao, G.; Wang, J.D. Synthesis 2009, 2035.

9. Shen, K.; Liu, X.H.; Cai, Y.F.; Lin, L.L.; Feng, X.M. Chem. Eur. J. 2009, 15, 6008.

10. Li, Z.; Ma, Y.; Xu, J.; Shi, J.; Hongfang, C. Tetrahedron Lett. 2010, 51, 3922.

11. Ranu, B.C.; Dey, S.S.; Hajra, S. 2002, Tetrahedron 58, 2529.

12. De, S. K.; Gibbs, R. A. Tetrahedron Lett. 2004, 45, 7407.

13. Majhi, A.; Kim, S.S.; Kadam, S.T. Tetrahedron 2008, 64, 5509.

14. De, S. K. J. Mol. Catal. A: Chem. 2005, 225, 169.

15. North, M. Angew. Chem., Int. Ed. 2004, 43, 4126.

16. Yadav, J.S.; Reddy, B.V.S.; Eswaraiah, B. Tetrahedron. 2004, 60, 1767.

17. Chen, W.Y.; Lu, J. Synlett. 2005, 2293.

18. Rafiee, E.; Rashidzadeh, S.; Azad, A. J. Mol. Catal. A: Chem. 2007, 261, 49.

19. Rahi, T.; Baghernejad, M.; Niknam, K. Chin. J. Catal. 2012, 33, 1095.

20. Nouri Sefat, M.; Saberi, D.; Niknam, K. Catal Lett. 2011, 141, 1713.

21. Wang, S.H.; Zhao, L.F.; Du, Z.M. Chin. J. Chem. 2006, 24, 135.

22. Shaabani, A.; Maleki, A.; Soudi, M.R. Catal. Commun. 2009, 10, 945.

23. Derikvand, Z.; Derikvand, F. Chin. J. Catal. 2011, 32, 532.

24. Paraskar, A.S.; Sudalai, A. Tetrahedron Lett. 2006, 47, 5759.

25. Karmakar, B.; Banerji, J. Tetrahedron Lett. 2010, 51, 2748.

26. Katsuyuki, I.; Hana, S; Jun-Chul, C.; Toshiyasu, S; Hiroyuki, Y. Tetrahedron 2010, 66, 1898.

27. Karmakar, B.; Sinhamahaparta, A.; Baran Panda, A.; Banerji, J.; Chowdhury, B. Appl. Catal., A. 2011, 392, 111.

28. Das, B.; Ramu, R.; Ravikanth, B.; Reddy, K.R. Synthesis 2006, 1419.

29. Tundo, P.; Perosa, A.; Zecchini, F. Methods Reagents Green Chem., Wiley: Oxford; 2007.

30. Pramanik, A.; Bhar, S. Catal. Commun. 2012, $20,17$.

31. Kiasat, A.R.; Noorizadeh, S.; Ghahremani, M.; Saghanejad, S.J. J. Mol. Struc. 2013, 216.

32. Teimouri, A.; Najafi Chermahini, A. J. Mol. Catal A: Chem. 2011, 346, 39.

33. Teimouri, A.; Ghorbanian, L.; Moatari, A. Bull. Chem. Soc. Ethiop. 2013, $27,1$.

34. Shargi, H.; Sarvari, M. H.; Eskandari, R. J. Chem. Res. 2005, 483.

35. Parida, K.M.; Pradhan, A.C.; Das, J.; Sahu, N. Mat. Chem. Phys. 2009, 113, 244.

36. Colomban, P.H. J. Mater. Sci. Lett. 1988, 7, 1324. 